\title{
Tissue Processor
}

National Cancer Institute

\section{Source}

National Cancer Institute. Tissue Processor. NCI Thesaurus. Code C62219.

An automated system used to process tissue specimens for examination through

fixation, dehydration, and infiltration. 